\title{
Inservice Elementary Teachers' Perceptions of Teaching Skills and Educational Settings in Implementing a Problem Based Learning Approach

\author{
Hyun-Dong Choi*
} \\ Department of Earth Science Education, Kongju National University, Chungnam 314-701, Korea
}

\section{문제중심학습 교수 실행의 능력과 교육 환경에 대한 초등 교사들의 인식}

\author{
최 현 동* \\ 공주대학교 지구과학교육과, 314-701, 충남 공주시 신관동 182
}

\begin{abstract}
The purpose of this study was to find out inservice teachers' teaching skills and relevant educational settings that could be applied to an instruction of problem-based learning (PBL). Participants have been instructed PBL teacher training programs and applied PBL into teaching and learning process. Three elementary teachers were selected to participate in the study, and data were collected with semi-structured interviews. The interviews of the teachers in relation to PBL were analyzed by two main topics: (1) the teachers' teaching skills required in PBL and (2) the educational settings in implementing PBL. The results are as follows: First, there is a difficulty involved in the implementation of PBL in that its preparation and teaching process are different from the traditional teaching methodology. However, as a helper who guides the students to self-directed learning in the free and permissible learning environment in which students are motivated to develop their potential effectively, the teachers are to invest their time consistently and to put their efforts into making an effective class in the entire process of PBL. Second, as a method to apply the problem-based learning to the education settings, the teachers must spread the awareness of PBL to fellow teachers, students, their parents and the administrators in education and form the community of the teachers. Most importantly, when the teachers apply PBL in the directly, from the joy of witnessing the changes in the students, they will choose to adopt PBL.
\end{abstract}

Keywords: Problem-Based Learning (PBL), PBL teacher's teaching skills, educational setting

요 약: 이 연구의 목적은 학교 현장에서 문제중심학습을 적용할 수 있는 초등 교사들의 교수 실행의 능력과 교육 환경 을 알아보기 위한 것이다. 참가자들은 초등학교 수준에서 문제중심학습을 강의하는 강사로 활동중이었다. 초등학교 교 사 3 인이 연구에 참여하였으며, 자료는 반구조화된 면담을 통해 획득되었다. 문제중심학습과 관련된 교사들의 면담은 두 가지 주요 주제로 나누어 분석되었다. (1) 문제중심학습에서 요구되는 교사들의 교수 실행의 능력 (2) 문제중심학습 을 적용할 수 있는 교육 환경. 연구 결과는 다음과 같다. 첫째, 문제중심학습은 전통적인 교수학습 방법보다 수업 준비 와 교수 과정에 어려움이 있었다. 그러나 문제중심학습에서 교사들은 자율적이고 허용적인 학습 분위기 속에서 학생들 이 자기 주도적인 학습을 할 수 있도록 안내하는 도우미로서 행동한다는 점에서, 학생들은 잠재능력을 효과적으로 계발 할 수 있는 동기를 부여받는다. 이를 위하여 교사는 문제중심학습 전체에서 효과적인 학습 활동이 이루어질 수 있도록 끊임없는 노력과 시간을 투자해야 한다. 둘째, 문제중심학습을 적용할 수 있는 교육적 환경을 위하여, 교사들은 동료 교사, 학생, 학부모, 교육 행정가들의 문제중심학습에 대한 인식의 확산과 교사들의 커뮤니티 형성해야 한다. 문제중심 학습의 확산을 위해 가장 중요한 것은 교사들이 직접적으로 교수 활동에 문제중심학습을 적용해 보는 것이다. 문제중심 학습을 하면 학생들의 변화가 나타날 것이고, 이러한 효과를 경험한 교사는 교수학습과정에 문제중심학습을 채택하게 될 것이다.

주요어: 문제중심학습(PBL), PBL 교사의 교수 능력, 교육 환경

\footnotetext{
*Corresponding author: ajagoda@hanmail.net

Tel: $+82-2-833-2860$

Fax: $+82-2-833-3453$
} 


\section{Introduction}

Problem-based learning (PBL) is the teaching strategy where the phenomenon in the complex real world is suggested in the form of an ill-structured problem for the student to search for meaningful answers on their own, thereby applying the formative approach which teaches the subject knowledge, process knowledge and problem-solving strategies all at the same time (Cho, 2003; Kim and Kwon, 2003).

PBL had its origin in the medical school but as a method to resolve the issues of traditional education methods, its effectiveness was tested and proven, bringing about a number of researches in the educational fields of elementary, middle school education as well as of education for adults (Achilles and Hoover, 1996; Gallagher and Stepien, 1995; Sage, 1996). In Korea, the attempts to converge PBL into elementary and middle schools have been actively in progress (Chang et al., 2005; Chung, 2007; Kim et al., 2004; Oh et al., 2005; Park, 2009; Park and Woo, 1999; Seo, 2007; Son and Ha, 2008). Recently PBL is becoming known as the useful method for web-based class using the Internet and information skills training and a number of researches have been focused on the effects of PBL using web (Choe and Kang, 2008; Kim, 2003; Park, 2004; Seo, 2002; Sung and Choi, 2006). Previous studies have displayed differences in the class contents and methods but generally they have reported that PBL is effective in terms of positive effects on the a sense of achievements on the part of the learners, problem-solving skill, self-directed learning, creativity, motivation to learn and interests and attitudes and raising the learning efficiency.

Empirical studies of PBL have demonstrated that students who have learned from PBL curricula are better able to apply their knowledge to novel problems as well as utilize more effective learning than students who have learned from traditional curricula (Hmelo, 1998; Hmelo and Lin, 2000; Schmidt et al., 1996). This finding is supported by Gijbels and colleagues' (2005) meta-analysis of learning outcomes in PBL versus traditional settings. Despite the positive research findings from most of studies on PBL, it has not been universally used in the school setting in Korea yet (Choi, 2004; Yoon and Woo, 2010). The teaching method mainly used in school is the lecture style and the teaching-learning materials provided for the class are still for the support for lecture-style classes (Jeong, 2007; Park and Jeong, 2006).

There have been a number of teachers who have shown interest in PBL, but they find it burdensome and difficult in actually applying PBL into their classes (Yoon and Woo, 2010). Schoenfeld (1998) found very different results between expert teachers and novice teachers in the analyses. The goals and beliefs that teachers hold help frame the problemsolving. Expert teachers lead the problem-solver to generate multiple hypotheses from student' initial presentation. They require the problem-solver to inquire for more information in order to refine these hypotheses and move toward a resolution.

In the study, all perspectives of the PBL instructing criteria will be examined. This will include all elementary school teachers who have been instructed PBL teacher training programs and teachers applying PBL into teaching and learning process within the school setting. In other words, the ones who are called the teachers in the field of PBL education have been analyzed. The research questions to be answered through this study are as follows.

First, what would be the teachers' teaching skills required for PBL?

Second, what are the educational settings in implementing PBL?

\section{Method}

\section{Participants}

The participants in the study include three teachers who are currently in 'PBL In-Depth Program for Growing Expertise of Classes in Elementary and Middle School Education' implemented by 'S' Education Training Center in 2010. Three elementary school teachers participated in the interview. They have been instructed PBL teacher training programs 
and applied PBL into teaching and learning process within the school level, teaching experience and PBL teacher experience for the teachers who took a part in the interview.

Mr. Choi got involved with PBL when he participated in the teaching training program held by 'C' Education Training Center in 2007, which became a chance for adopting PBL to school setting. He has two years of experience implementing PBL in the setting of elementary school education and 1 year experience as a PBL instructor. Also he received the degree of doctor of philosophy of education in 2008. Mr. Chang became interested in PBL while pursuing his master's degree. He wrote a thesis on e-PBL based on the subjects of elementary school students. He has four years of consistent PBL style instruction in the setting at elementary schools and 3 years in PBL instruction. Mrs. Chung became intrigued with research results on the positive effects of PBL and has been applying PBL in educational setting with two years of experience in PBL instruction.

The commonality among the three people is the fact that they have first became acquainted with PBL in their graduate program and by actually conducting PBL class themselves, they admittedly said that they have become fanatical proponents of PBL. For an effective learning method for the students, these teachers are advocating for PBL, and as a chance for becoming PBL instructors, they have a form community for themselves.

\section{Data collection}

For the data collection, after explaining the contents and objective and interview materials were explained to the research subjects in detail the researcher was given their consent form. Based on the open-edned indepth interview and semi-structured interview schedule, the interviews conducted with flexibility and application according to the situations and the research subjects were allowed to freely discuss their thoughts and experiences. Interviews usually took about 40 minutes to one hour. The results of the interviews were recorded by the camcorder and later transcribed to be given feedbacks by the relevant teacher.

\section{Data analysis}

The details of the interviews were analyzed by type by deriving the main discussion topics for the teachers in relation to PBL. The main issues regarding PBL were two and the category of the issues were (1) the teachers' teaching skills required in PBL and (2) the educational settings in implementing PBL. By analyzing each category, the answers were applied to all relevant categories. The questions for the study are shown in Table 2.

Since the data collected show each teacher's subjective viewpoints about PBL, this study carried out cross-case analysis by taking it into consideration that teachers have various different ideas. In other words, this study compared and contrasted all the

Table 1. Teaching experience, last educational level and PBL instructor experience

\begin{tabular}{ccccc}
\hline \hline Teachers & Gender & Last educational level & Teaching experience & PBL Instructor experience \\
\hline Mr. Choi & Male & Ph.D. & 18 & 1 \\
Mr. Chang & Male & Masters & 20 & 3 \\
Mrs. Chung & Female & Masters & 9 & 2 \\
\hline
\end{tabular}

Table 2. Issues regarding PBL

\begin{tabular}{cl}
\hline \hline Categories & Sub categories and question \\
\hline $\begin{array}{c}\text { Teachers' teaching skills } \\
\text { required in PBL }\end{array}$ & $\begin{array}{l}\text { - What were the most difficult parts in preparing for PBL and applying it to educational setting? } \\
\text { - What do you think is the role of teacher in PBL? }\end{array}$ \\
\hline $\begin{array}{c}\text { The educational settings } \\
\text { in implementing PBL }\end{array}$ & $\begin{array}{l}\text { - What are the points to consider when conducting your class in PBL format? } \\
\text { - What do you think is the driving force behind continuous application of PBL in the educational setting? }\end{array}$ \\
\hline
\end{tabular}


cases with one another in order to find out whether there were similarities among teachers. Through such a process, it was possible to prevent researchers from conducting a relative analysis of teachers' various different ideas and grasp distinct characteristics that each case has. In addition, it was because the accuracy, validity and stability of the research analysis results could be reinforced as well.

For the validity of analyzing data collected, this study had information providers conduct feedback and member checking for the research results. To analyze teachers' PBL, this study made teachers reevaluate the contents of each interview and the results of analyses. This work was for the reliability of analyses, that is, the inner validity. When clearness-lack aspects or new problems took place during the process of analyzing the data, researchers discussed them with the related teacher. Throughout the process of carrying out analyses and drawing conclusions, this study tried to exclude researchers' bias and subjectivity and to make them take straightforward attitude.

\section{Results and Discussion}

The teachers skill required for PBL and the method for applying PBL suggested by the teachers who are instructing $\mathrm{PBL}$ in the teachers training program and practicing PBL examined are as follows.

\section{Teachers' teaching skills required for PBL}

The difficulties of problem-based learning class: The teachers have said that the biggest difficulties lie in preparing various materials that can stimulate understanding and interests in the problems in a series of processes ranging from presenting problems, performing assignments, presentation and assessment as well as in preparations for having students get adjusted to the learning environment PBL provides. They discussed any difficulties from securing time for developing problems and consistent feedbacks on the part of the teachers to making certain progresses in a specified time.

Another issue involves the confusion and lack of communication between the team members leading to the delay in the learning process on the part of the students due to the lack of understanding on the nature of PBL which requires autonomy. The students sometimes felt burdened by a considerable amount of learning materials and experienced difficulties.

Mr. Chang: The main issue with PBL lesson is the problem, right? But, it seems quite difficult to develop those problems. Not only analyzing the unit but preparing the first draft for the topic, going over it and completing scenarios takes up a lot of time for me and I do put in a lot of time for it. The problem needs to be able to attract the interests of the students in order to challenge them, too.

Mr. Choi: When we first apply the PBL lesson, the children have difficulty getting adjust to it. For instance, when they're supposed to search for information to solve the problem, they just download things on the Internet and bring them to me for homework. They are so used to that to the point where they can't get to the solutions to the problem. The process of understanding the answers is more important, but one lesson isn't enough for that.

I think the teacher should put effort into it. In my case, what is most difficult is that I tend to give attention to students and give individual feedback, which takes up a lot of effort on my part. It takes more energy since you can't just talk during the class and get it over with but you need to keep talking to the students even after the school is over.

Mrs. Chung: Students are used to the previous way of class. They are used to the teacher-centered lecture and memorizing what they learned for testing. In case of PBL class, students themselves set the objective for the lesson, solve problems and lead the presentations for sharing their results to the class. The element of independence is too much at first and the children get very confused. The most difficult aspect for me to teach a class, initially was children's rigid way of thinking. 
Mr. Chang: Unlike regular classes, it requires much to learn from the students. Besides classes at school, I ran team activities after-school or at home. But students these days, they mostly go to private schools. So it's difficult scheduling the time between team members and that presents difficulties, I think.

Although the existing educational researches on the problem-oriented study show positive results, it is not universally applied in school sites. A main reason is probably because the problem-oriented study requires teachers to take a position as an education designer. One of the main characteristics of the problemoriented study is that teachers themselves should suggest problems, manage students' assignment performance and actively work out the presentation and the evaluation of students' results. Moreover, when teachers have made students understand the entire program, students will be able to take part in the problem-oriented study voluntarily. Accordingly, PBL teachers should have high-level professional roles and determination as a program developer.

The key to applying the principles of PBL depends on what question has been utilized and developed (Choi, 2004). The teacher's expertise would be required for designing what type of questions and how. Im (2002), Cho (2003), Choi (2004) and others have suggested the establishment of problem banks for PBL and specific guidelines for creating problems as a method to resolve the difficulties for the teachers in the stage of developing problems. Such attempt is a wonderful method to make the use of PBL in school setting more active. Based on this, the teachers would be able to easily understand the nature of problems to be developed and used in PBL and by what criteria PBL must be assessed.

The role of teachers in PBL: The teachers seemed to think that the teachers must lead the students into more self-directed learning and for this, they should create a more permitting learning environment, where the students can utilize their potential to the fullest. As for the role of teachers in PBL, Mrs. Chung and Mr.
Chang thought that the role of a helper was important, while Mr. Choi emphasized that individualization has to be focused on, not the overall aspect of the teachers' role. As a helper, Mr. Chang suggested the instruction methods of more effective progress of the overall class such as peaking students' interests, forming groups, informing parents and making schedule.

Mr. Choi: Whereas the traditional class style is onesided where teachers teach the students, PBL class' main objective is the self-directed learning. For this, it is essential that teachers lead the students to learn in more self-directed manner, rather than the teacher instructing them in one-sided way. So the first and foremost, how the learning environment is created and provided is important.

Mrs. Chung: I think for children to utilize their potential, we need to create a freer and more flexible learning environment for them. Not directly getting involved in the way of learning but acting as their helper so that they could perform better at their side is the key role for the teacher, I believe.

Mr. Chang: The students setting up the overall goal, coming up with plans for the process, putting them into practice and creating results and sharing themthat series of process needs to be aided by the teacher as their helper and facilitated learning, which is different form of role as a teacher from previously.

Mr. Choi: When I was in school, I met teachers on a daily basis, but I really did not get a chance to have conversations on a personal level. PBL lesson, there has to be constant communication between the teacher and the student. By communicating, you can find out how the learning is happening individually and figure out whether or not the student has really understood the material. Sometimes, you can give those compliments and praises and give students feedbacks. It appears that these processes are always customized, so the role of the teacher is oriented towards 
individualization, and not as whole. I felt that through PBL class, individualized learning is possible.

Mrs. Chung: When I was instructing the unit on weather for sixth graders, I formulated lesson that the weather's for sale. In science class, when I was teaching them about Earth Science to students, they found it really boring. The sixth grade students weren't that interested in weather other. But when I came up with the problem 'weather marketing' they sudden showed interests.

Then I set up the teams during the class and sent the parents the letters that informed what lessons are prepared and how the children must be spared some time for it.

Then the students were able to match up their schedule and the class turned out fun. The results were quite satisfactory, as I remember. Wouldn't the role of the teacher be overseeing the overall process of the class? I saw the results then, and I conduct most of the PBL classes that way.

In problem-based learning, teachers come to perform different role from the one in the existing teachinglearning method. As previously mentioned by the teachers in the study, the teachers in the traditional class mainly performed a role of teaching all concepts involved with the problem or core topics to the learners first and communicates knowledge. However in PBL, the teacher first presents a problem (Allen et al., 1996) and takes on the role of the 'cognitive coach' who guides the search for the students and comes up with modeling the search strategies in their path to search for the problems and assist them in clearly recognizing the research questions for solving them (Arambula-Greenfield, 1996).

In the study, the teachers have stated that the role of the teacher in PBL is that of a helper. A number of existing researches about PBL have specified the role of the teachers for the vitalization of the self-directed search and thinking on the part of the learners as the 'facilitator' or 'guider' (Allen et al., 1996; HmeloSilver, 2004).
The results of this study may not be really different from those of the existing theoretical contents or research results, which indicates that research subjects have been fully aware of their roles as a teacher that the existing PBL researches should have.

The PBL process is a student-centered as contrasted with a teacher-centered. The students are encouraged to become responsive to challenges they encounter and are responsible for their own learning. The PBL teacher, in the facilitator role, guides rather than directs students' learning. The teacher acts as an educational tutor-facilitator throughout or coach rather than an authoritative dispenser of information.

Specialized teaching skills required for teachers in PBL: As for the specialized teaching skills required for teachers in PBL, the teachers have reported that they think restructuring the 'problem' which is the key to PBL as the contents teacher is crucial. Furthermore they stressed the expertise of the teachers across all processes of PBL from advance preparations, problem developments, the establishment of learning environment designs, design of overall learning process and assessments. Mr. Chang compared the learning space with the perfectly equipped playground and stressed that the teachers must prepare various playthings for the use of the students.

On the other hand, current PBL utilizes e-PBL class based on the Internet. Regarding this, the teachers have stated that the teachers' ICT user ability could turn out to be a strong advantage in leading PBL classes but cannot be a limiting factor.

The teachers have determined if the teachers do not have ICT skill, though it may present limitations in creating learning environment, it would not be too problematic since they could use the existing portal sites or cafés offered. Also, they added that fun PBL classes are possible off-line as well and they should not be too pressured about being equipped with ICT skill. In particular, Mrs. Chung provided an example of his 'fossil museum' class which he operated and emphasized that blended learning which can be performed both on-line and off-line learning can make 
PBL more successful.

Mr. Choi: The key to PBL class is developing problems, so the making of PBL problem which combines with the learning objectives of the unit they are to learn as the contents teacher should be the important role for the teacher.

Mr. Chang: You also need to prepare the necessary questions and what to provide for learning supports in various mediums for the flow of learning for the children in advance for children to do in the overall learning environment. For instance, once you build a playground for the children, the choice to ride on the slides, swings or other playthings is entirely up to the children. So the role of making the playground should be done by the teacher. The teacher has to oversee developing questions, establishing learning environments, designing overall process and preparing things for assessment which would mean that the expertise on the part of the teacher is required unlike previously.

Mrs. Chung: The fossil museum I was teaching was designed in the blended learning style where you develop on-line learning and problems on your own and apply them while performing off-line learning. The effects were phenomenal. The communication and researching for data between students happened in cyber space and explanations for the learning materials, question and answers and actual practice during class were done off-line. If the teachers use the internet to the extent where they check the class results the students uploaded, using the internet should not be too taxing for the teachers.

Mr. Chang: without ICT function, PBL class can be developed in interesting ways.

PBL class itself was not suggested in the e-Learning environment but it was created over a couple of decades. So having interesting PBL classes can be certainly possible in the off-line environment as well.

The teachers all agreed on the fact that the role of the teacher required in PBL is that of the promoter and a guider. Then how must they perform such roles? What would be the further specialized requirements of the teacher in PBL? Regarding this, the teachers who participated in the study have said that they think overseeing the effective proceeding of a series of process of PBL is the role of the PBL teachers and the specialized skill.

As curriculum designer, the typical teacher's role changes from implementing externally made curriculum decisions to being a highly involved decision-maker in the curriculum planning process. The teacher's challenge is to select and structure problems so that they address both the important content objectives of the curriculum and important real-world issues.

Recently the web infrastructure for PLB using the Internet has been widely used. If the education that occurs on-line space is called cyber education or eLearning system, the school could utilize blended learning to improve the learning effects. Blended learning overcomes the contracts of time and space of the traditional face-to-face educational method through e-learning and optimizes its educational strengths appropriately, maximizing the learning effects (Chang and Park, 2007).

Thus the strategies to properly blend on-line and off-line learning environments, various learning methods and assignments would be required for the teachers, thereby bringing about the favorable learning outcomes. However, as demonstrated in this study, specialized ICT skill for the teachers cannot be said to be critical. In PBL, the cyber space's that can be utilized by the students are already provided by the school homepage or portal sites with ease.

\section{The educational settings in implementing PBL} Issues to consider when applying PBL to the educational setting: PBL teachers all agreed that it was crucial to watch the students with patience and faith that they will be successful to the end. The visible outcomes are not directly produced in PBL and more gradual effects will be observed if $\mathrm{PBL}$ is implemented in a consistent manner. Especially the 
hearts of the teachers caring for the students must be present in the background for them to invest much of their time.

Mr. Choi, stresses the need for teachers to think of forming small groups since PBL works in activities in small group basis. PBL, generally works centered on small groups, and thus he is of the opinion that the teachers must be concerned with the makeup of the group and the interaction between the group members.

Mrs. Chung: It's highly important that you have patience and be able to wait while believing that the children can do it. It is crucial that you do not cease to stop believing. Learning does not take place because the teachers have communicated it well but the children themselves formulate the knowledge whether it may take place in their heads or minds.

I believe PBL class would be successful once the teachers have the faith that the students will see to it till the end.

Mr. Chang: If the teachers have passion to improve their classes through PBL consistency should be the most important factor, whether it be once a week, twice a month basis. Then you will really begin to see the real value of PBL.

On the other hand, according to Delisle (1997), PBL is generally implemented centered on small groups and thus, the teachers' feedbacks must focus on the small groups learning what, and by how. He asserted that rather than vague and generic assessment, more clear, positive and detailed assessment would be more appropriate. Therefore, the teachers should place special interest in the formation of the group and the interaction between the group members in the small group activities.

Mr. Choi: PBL classes generally happens in smallgroup setting so what kind of small groups they're in could be the factors for variations in whether they can successfully complete PBL class. From my experience, the improvements in students are greater when they're in homogeneous group than they're in heterogeneous groups. I think it is perhaps more respectful attitude towards each other can be found in the homogenous group.

Motivation behind the application of PBL into educational setting: The teachers picked as the strongest strength of PBL as the sense of achievements they experience through watching the students. They have stated that the joy for the teachers by watching the students asking questions voluntarily, discussing information amongst themselves and showing continued interests after the classes are over, was more rewarding than any other awards. In addition, they said that the improvements in students' decision making ability and presentation skills, communication skills and the forming of debate culture are parts that are fulfilling for the teachers.

Mr. Chang: I think it's addictiveness. In other words, when the teachers see the children feeling the joy from it, they have no choice but to continue with it. In my case, there have been many times where I did not get adjusted to the class that day and I was struggling with it. So I thought I would try something different. Then I applied the new things into PBL and I see the children experiencing joy from learning. Then I thought, 'Oh! I know it'll take a lot out of me but let's try PBL class next time too!' and that ends up being continuous.

Mrs. Chung: For PBL, as soon as I open the classroom door, I get a swarm of students running towards me asking questions related to the class and divulging the new information they found. You don't see that in regular, general classroom. Students try really hard and focus on the classroom, and they voluntarily keep asking questions. When the class is over, too, they come in twos and threes and discuss about the class. When I see them discussing how this source is great and that source is better together and this kind of things happening continuously inside the 
school, I realized, "Wow, they're really enjoying the class." That is how I get to feel more sense of obligation and responsibility for the PBL class which the teachers should pay more attention to for the sake of learning.

Mr. Choi: From where teachers stand, since children are excited about it, they end up excited about it too. I think it is quite possible as long as the teacher has the affection for the children. Even it may be a bit difficult, when the teacher feels the joy the children feel for himself or herself, that difficulty cannot be a hurdle for continuing with PBL lesson.

PBL consists of a series of procedures such as the presenting of problems, the discovery of problems, debates and the presentations on the findings. The teachers must encourage the participation of the students in the all steps of the process and provide appropriate information so that the students will not deviate from the given problem (Aspy et al., 1993). In such process in the class, they must guide the students specifically as to what will be taught to them and how, thereby instilling a sense of accomplishments in the process of solving the problem in a self-directed manner on the part of the students (Delisle, 1997).

However as mentioned by the teachers in the study, in order to solve the internal and external issues, the teachers' courage in attempting PBL radically even when their understanding of it may be lacking, is the most crucial. By conducting classes in PBL method, the joy from students concentrating on the class can be transferred to the teachers, thereby encouraging more teachers to adopt PBL.

In this context, the term 'addictiveness' as mentioned by Mr. Chang in the study implies something significant. To experience this addictiveness, the new attempts by the teachers are essential. Based on such attempts, the teachers who have experienced the addictive nature of PBL could form a community of their own naturally.

As aforementioned in the study, such self-directed sense of accomplishments in students turn out to be the motivation behind the teachers' willingness to invest their passion and the time into the class.

The method for expansion of PBL in school setting: The teachers in the study have determined that the understanding for PBL by the teachers, students, and their parents would be essential in settling the PBL in school setting. Moreover they believed that systemized support and the expansion of training opportunities the office of education and the school administrators for active communities amongst teachers could provide an opportunity for more teachers to experience PBL and support it.

Most importantly the teachers who participated in the study have forecasted that once the teachers had a chance to experience PBL, they would acknowledge the strengths PBL and adopt PBL actively. For this to happen, they suggested the teachers to challenge the areas they are confident in even when they are not too familiar with how PBL works. As for the reasons for this, Mr. Chang was certain that once the teachers apply PBL into their classes, they are sure to share the joy.

Mrs. Chung: It's important for the teachers to have deep understanding of PBL, but the children also need to the understanding of what PBL class is. Then they would know with what attitude they should be coming into the class for PBL classes and be more successful at it.

Mr. Choi: Because PBL requires the cooperation of the parents, you need the letters to the parents for implementing PBL lessons. I want to add that the letters to the parents must be sent to the parents to make them aware that computers are not for entertainment tool but for learning and that is quite important.

Mr. Chang: I think the community must be established between teachers as well. It is really taxing for one single teacher to lead PBL class alone. I think it would be really great for teachers with passion for 
PBL to gather as a small group, sharing problems and giving each other feedbacks for developing it. In this light, more systematic supports could be provided like organizing research center by the office of education or offer opportunities for teachers to learn about PBL through training programs. Or if possible, for classes like that to be encouraged in schools, I think it is essential that the principals, vice principals and people in that rank must be informed of classes like PBL.

Mr. Chang: It's very important that even the teacher does not know PBL fully, they at least give it a try once. Then you can get this joy that PBL class has something that stands out which can have students focus on the class. They should start with something they're best at first. Once they give it a start, they will feel a joy from the students actually putting their efforts to learn something. So if the teacher is experienced in science, it would be a great experience for them to start the PBL problem in relation to the subject of science. For example, I'm quite interested in computers. Since I know a bit about computers, I could demand that much from the students in the field. So I came up with PBL questions and applied into my class. That very first class gave me so much joy.

An understanding about PBL by the teachers, students, their parents and educational authorities must precede as a method to resolve the external issues. In particular, expansion of educational training program for a number of teachers to experience PBL would be required since the teachers are placed in a critical place where they can select the educational method at the setting. For this the expansion of educational research committee or educational training programs would be needed primarily.

In this study, teachers insist that teachers, students, parents and education officials should understand the problem-oriented study in advance, as a plan to rapidly spread the problem-oriented study into school sites.

\section{Summary}

PBL is a total approach to education. In PBL there is a curriculum of carefully selected and designed problems. In the PBL Process, students work through a series of problems designed to be authentic and to target defined areas of the curriculum. Students assume the responsibility for learning and teachers become facilitators: stimulating and guiding students' in their problem solving.

The PBL teacher, in the facilitator role, helps rather than directs students' learning. The PBL teacher acts as an educational tutor-facilitator throughout or coach rather than an authoritative dispenser of information. The PBL teachers in the study stressed for this, patience is more crucial than anything for the teacher. The PBL process is a student-centered as contrasted with a teacher-centered. The students are encouraged to become responsive to challenges they encounter and are responsible for their own learning.

As a curriculum designer, the typical teacher's role changes from implementing externally made curriculum decisions to being a highly involved decision-maker in the curriculum planning process. The PBL teacher's challenge is to select and structure problems so that they address both the important content objectives of the curriculum and important real-world issues.

Resources include not just print materials but computer, media and human resources as well. Because this PBL method keeps the role of facilitator separate from the role of content expert, teachers serve as content experts only to the extent of their expertise and only when approached by students. The PBL teacher in the role of content resource appropriately calls on the entire repertoire of techniques for helping students acquire the knowledge and skills they have identified.

An understanding about PBL by the teachers, students, their parents and educational authorities must precede as a method to resolve the external issues. The PBL teachers are placed in a critical place where they can select the educational method at the setting. 
The PBL teachers should keep trying to understand them: fellow teachers, students, parents, educational authorities. In this context, the expansion of educational research committee or educational training programs would be needed primarily. Also the teachers who have experienced the addictive nature of PBL could form a community of their own naturally.

\section{Conclusion}

The research was conducted in a form of interviews on the subjects of teachers who are instructing PBL in the teachers' training program while implementing it. In this study, the difficulties of PBL in relation to the role of teachers and the teachers' role in PBL as well as points to consider when designing PBL as the application method for educational setting, the motivation behind continuous application of PBL and applicable method of PBL were examined.

The PBL teacher helps rather than directs students' learning. The PBL teacher should act as an educational tutor-facilitator throughout or coach rather than an authoritative dispenser of information. The PBL teachers in the study stressed for this, patience is more crucial than anything for the teacher. And the PBL teacher's challenge is to select and structure problems so that they address both the important content objectives of the curriculum and important real-world issues.

An understanding about PBL by the teachers, students, their parents and educational authorities must proceed as a method to resolve the external issues. The PBL teachers should keep trying to understand them: fellow teachers, students, parents, educational authorities. In this context, the expansion of educational research committee or educational training programs would be needed primarily. Also the teachers who have experienced the addictive nature of PBL could form a community of their own naturally.

PBL has been attempted with the consideration of effective application method and teachers' skill suggested by the teachers who are implementing PBL in education setting and lecturing about PBL in teachers' training program, any teachers with the affection for their students would be able to demonstrate the values of PBL in their class.

\section{References}

Achilles, C.M. and Hoover, S.P., 1996, Transforming administrative praxis: The potential of problem-based learning as a school-improvement vehicle for middle and high schools. Paper presented at the annual meeting of the American Educational Research Association. (ERIC Document ED 397471).

Allen, D.E., Duch, B.J., and Groh, S.E., 1996, The power of Problem-Based Learning in teaching introductory science courses. New Directions for Teaching and Learning, 68, 43-52.

Arambula-Greenfield, T., 1996, Implementing problembased learning in a college science class. Journal of College Science Teaching, 88, 26-30.

Aspy, D.N., Aspy, C.B., and Quimby, P.M., 1993, What Doctors can teach teachers about Problem-Based Learning. Educational Leadership, 50, 22-24.

Chang, K.W. and Park, M.H., 2007, Research on effective learning space using for blended PBL. Journal of Learner-Centered Curriculum and Instruction, 7, 207232.

Cho, Y.S., Lee, H.J., Baek, E.J., and Lim, H.H., 2003, An instructional model of structured academic controversies in problem-based learning with internet. The Journal of Curriculum Studies, 21, 215-242.

Choe, U. and Kim, M.S., 2003, Research on effective learning space using for blended PBL. Journal of Korean Association for Educational Information and Media, 9, 101-134.

Choi, J.I., 2004, A study on the problem design principle for Problem-Based Learning through the case analysis. Journal of Educational Technology, 20, 37-61.

Chung, H.M., 2007, A case ctudy on web-based PBL course: Focus on the design of reflection supporting tool and its effects. Journal of Korean Association for Educational Information and Media, 13, 161-196.

Delisle, R., 1997, How to use problem-based learning in the classroom. Association for Supervision and Curriculum Development, Alexandria, USA, $107 \mathrm{p}$.

Gallagher, S.A. and Stepien, W.J., 1995, Implementing problem-based learning in science classrooms. School science and mathematics, 95, 136-146.

Gijbels, D., Dochy, F., Bossche, P.V.d., and Segers, M., 2005, Effects of Problem-Based Learning: A meta-analysis from the angle of assessment. Review of Educational Research, 75, 27-61.

Hmelo, C.E. 1998, Problem-based learning: Effects on the 
early acquisition of cognitive skill in medicine. Journal of the Learning Sciences, 7, 173-208.

Hmelo, C.E. and Lin, X., 2000, Becoming self-directed learners: Strategy development in problem-based learning. In Evensen, D. and Hmelo, C.E. (eds.), Problembased learning: A research perspective on learning interactions. Erlbaum, NJ, USA, 227-250.

Hmelo-Silver, C.E., 2004, Problem-Based Learning: What and how do students learn? Educational Psychology Review, 16, 235-266.

Im, J.H., 2002, National supporting for PBL (ProblemBased Leaming) in classrooms. The Korean Journal of Educational Methodology Studies, 14, 69-82.

Jang, S.J., Jeong, M.S., and Park, W.H., 2005, The effects of Problem-Based Learning on science education: Focus on characteristics of life. The Korean Journal of Biology Education, 33, 1-12.

Jeong, H.H., 2007, Incongruity of Classroom Instruction and e-Learning in Elementary School: From Observation through the Ecological Perspective. The Journal of Educational Information and Media, 13, 5-51.

Kang, S.H., 2008, The effect of a realtime PBL cyber science class on self-regulated learning and learning attitude of middle school students. The Journal of Educational Information and Media, 14, 51-72.

Kim, K.J. and Kwon, B.D., 2003, An application of Problem Based Learning to an earth science course in higher education. Journal of Korean Earth Science Society, 24, 108-116.

Kim, T.E., Jeong, M.S., and Park, W.H., 2004, Design and application of PBL programs of life unit in high school science. The Korean Journal of Biology Education, 32, 316-324.

Mergendoller, J.R., Maxwell, N.L., and Bellisimo, Y., 2006, The effectiveness of problem-based instruction: A comparative study of instructional methods and student characteristics. The Interdisciplinary Journal of Problembased Learing, 1, 49-69.

Oh, H.J., Kim, S.D., and Lee, Y.S., 2005, The effect of Problem-Based Learning on student's creativity in middle school class. Journal of Korean Earth Science Society, 26, 1-8.

Park, I.W. and Jeong, H.H., 2006, A analysis of teachers', students', and parents of students', awareness on eLearning of the elementary school instruction situation. The Journal of Educational Information and Media, 12,
197-230.

Park, J.W. and Woo, O.H., 1999, The effects of PBL (Problem Based Learning) on problem solving process by learner's metacognitive level. Journal of Educational Technology, 15, 55-82.

Park, S.K., 2004, Effect of Cooperative skill training on Problem Based Learning for science class. Journal of Korean Earth Science Society, 25, 327-335.

Park, S.K., 2009, The application of the Problem Based Learning model in science classes and analysis of it's effects. Journal of Science Education, 33, 353-364.

Sage, S.M., 1996, A qualitative examination of problembased learning at the K-8 level: Preliminary findings. Paper presented at the annual meeting of the American Educational Research Association. (ERIC Document ED 398263).

Schmidt, H.G., Machiels-Bongaerts, M., Hermans, H., ten Cate, T.J., Venekamp, R., and Boshuizen, H.P.A., 1996, The development of diagnostic competence: Comparison of a problembased, an integrated, and a conventional medical curriculum. Academic Medicine, 71, 658664.

Schoenfeld, A.H., 1998, Toward a theory of teaching-incontext. Issues in Education, 4, 1-94.

Seo, G.S., 2002, Actual effect of web-based PBL model. The Korean Journal of Educational Methodology Studies, 14, 45-68.

Shon, M. and Ha, J.M., 1996, A meta-analysis on the effects of Problem-Based Learning. The Journal of Educational Information and Media, 14, 225-251.

Suh, Y.W., 2007, An elementary school Teacher's role in constructing authentic and contextual Problem-Based Learning environment: Focusing on how to use teaching strategies and materials for 4th grade science unit 'Energy'. The Journal of Elementary Education, 20, 75111.

Sung, E.M. and Choi, W., 2006, The Effects of An Instructional Model of Problem-Based Inquiry Learning with Internet on Inquiry Capability, Academic Achievements, and Retention of Elementary School Student. Journal of Korean Association for Educational Information and Media, 12, 129-159.

Yoon, H.J. and Woo, A.J., 2010, Secondary school teachers' perception and their application methods of Problem-Based Learning. Journal of Korea Association Science Education, 30, 621-635. 